\title{
Silvopastoral Systems Contribute to Water Buffalo Welfare and Normal Behavior Pattern Under Eastern Amazon Conditions
}

\author{
Núbia de Fátima Alves dos Santos \\ Universidade Federal Rural da Amazônia - UFRA, Belém, Brazil \\ E-mail: nubia.santos@ufra.edu.br \\ https://orcid.org/0000-0001-7725-1412 \\ Jamile Andréa Rodrigues da Silva \\ Universidade Federal Rural da Amazônia - UFRA, Belém, Brazil \\ E-mail: jamileandrea@yahoo.com.br \\ https://orcid.org/0000-0002-6400-6925
}

Airton Alencar de Araújo

Universidade Estadual do Ceará - UECE, Fortaleza, Brazil

E-mail: aaalencar2002@yahoo.com.br

https://orcid.org/0000-0002-6636-3803

Rinaldo Batista Viana

Universidade Federal Rural da Amazônia - UFRA, Belém, Brazil

E-mail: rinaldo.viana@ufra.edu.br

https://orcid.org/0000-0002-7540-585X

Alexandre Rossetto Garcia

Embrapa Pecuária Sudeste, São Carlos, Brazil

E-mail: alexandre.garcia@embrapa.br

https://orcid.org/0000-0002-3354-1474 
Andréia Santana Bezerra (Corresponding author)

Universidade Federal do Pará - UFPA, Belém, Brazil

E-mail: andreiazootecnistaufra@gmal.com

https://orcid.org/0000-0002-9611-3266

\author{
Benjamim de Souza Nahúm \\ Embrapa Amazônia Oriental, Belém, Brazil \\ E-mail: benjamim.nahum@embrapa.br \\ https://orcid.org/0000-0002-1143-706X
}

José de Brito Lourenço Júnior

Programa de Pós-graduação em Ciência Animal - UFPA-Embrapa-UFRA, Belém, Brazil

E-mail: joselourencojr@yahoo.com.br

https://orcid.org/0000-0001-6441-4577

Received: December 3, 2020

doi:10.5296/jas.v9i2.18022
Accepted: March 10, $2021 \quad$ Published: March 25, 2021

URL: https://doi.org/10.5296/jas.v9i2.18022

\begin{abstract}
This research aimed to study the behavior of female Murrah buffaloes in a silvopastoral system. The trial was carried out at Embrapa Eastern Amazon, under Afi climate according to the Köppen classification, between August and November 2009, during the less rainy season. Three different periods of the day were considered during activity evaluation: morning period - between 6:00 AM and 9:55 AM; intermediary period - between 10:00 AM and 1:55 PM; and afternoon period - between 2:00 PM and 5:55 PM. The animals were maintained in a silvopastoral system (SPS) ( $\mathrm{ST} ; \mathrm{n}=10)$ with shade from Racosperma mangium. The meteorological variables of temperature and relative air humidity were measured, as well as the following animal behavior variables: time grazing, ruminating and idling, time standing and lying, and time in shaded and non-shaded areas. These variables were compared by $\mathrm{T}$ test $(\mathrm{P}<0.05)$. Air temperatures were higher in the non-shaded area of the SPS. All activities were reduced in the intermediary period, except idling. The grazing and rumination times in the morning were longer in non-shaded areas, while the time idling standing was longer during the intermediary period in shaded areas as a way of avoiding the harmful effects of the
\end{abstract}


intense solar radiation and high air temperatures of the Amazonian humid climate. Hence, SPSs may contribute to animal welfare and increase their productive behavior.

Keywords: Amazon, ethology, water buffalo, thermal comfort

\section{Introduction}

Cattle adaptation to the climate and management conditions prevailing in tropical regions represents one of the greatest barriers for herd productivity, including in some regions of Brazil. Therefore, minimizing the harmful effect of the climate on animals in tropical and subtropical countries has been a constant concern in order to decrease the harmful action of the climate variables deemed responsible for thermal stress (Pezzopane et al., 2019; Marai and Haeeb, 2010). Such discomfort may be mitigated by management programs that lead the animals to cool down through shading, installation of fans and nebulizers, or the use of natural resources and appropriate facilities to reduce thermal stress (Giro et al., 2019; Parola et al., 2012).

Under thermal stress, the animals change their stance to better dissipate heat with the wind, and they also stay more still so as to minimize the heat generated by ambulation. Among other behavioral changes, their food intake patterns are altered due to less time dedicated to grazing and rumination. Overall, food intake by animals in the field decreases when the ambient temperature is higher than $26^{\circ} \mathrm{C}$. In animals raised in the tropics, nighttime grazing may represent $60 \%$ of the total time dedicated to feeding (Rhoads et al., 2009). Thus, silvopastoral systems (SPS) are a modality of agroforestry systems with animals, forage plants, and trees in the same area that could be adopted to provide thermal comfort for animals through the shade provided by trees.

Therefore, this research aimed to study the behavior of female Murrah buffaloes raised in a silvopastoral system in order to design strategies to increase animal welfare in the climate conditions of the eastern Amazon.

\section{Material and Methods}

\subsection{Period and Experimental Site}

This experiment was conducted at Brazilian Agricultural Research Corporation - Embrapa Eastern Amazon (1 $1^{\circ} 28^{\prime} \mathrm{S}$ and $\left.48^{\circ} 27^{\prime} \mathrm{W}\right)$, in Belém, PA, Brazil, under Afi climate (Köpen). The rainier season lasts from January to July and a less rainy season lasts from July to December, the average air temperature is $26.8{ }^{\circ} \mathrm{C}$, annual rainfall is $2,876.9 \mathrm{~mm}$ and the average relative air humidity reaches $83 \%$ (Pachêco et al., 2009). Experimental procedures were previously approved by the Internal Technical Committee of Embrapa Eastern Amazon.

Animal behavior data were collected for four months during the less rainy season, between August and November 2009, when thermal stress is greater and would lead to more representative evaluations of the effects of the environment, mainly shading, on animal behavior.

The animal management area had 5.84 ha and was divided into three pens used for intensive 
rotational grazing of false creeping paspalum (Brachiaria humidicola) with a stocking rate of 0.8 A.U. ha-1 and 1.2 A.U. ha-1, respectively, at the beginning and at the end of the experimental period, using a 45-day grazing cycle with 15 days of occupation and 30 days of rest.

Four years prior to the experiment, Racosperma mangium saplings were planted along the fences four meters apart in $60 \mathrm{~cm}$ × $60 \mathrm{~cm}$ x $60 \mathrm{~cm}$ pits, fertilized with buffalo manure (100 $\mathrm{g} / \mathrm{pit}$ ) and $300 \mathrm{~kg} . \mathrm{ha}-1$ of natural reactive phosphate containing 33\% P2O5 aiming at promoting fast growth. The trees were intended to improve the animal ambience and add value to the ranch by implementing the SPS, according to the recommendations of Falesi and Baena (1999). By the year of the experiment, shading was estimated at $10 \%$ of the area. The dividing and perimeter fences were electrified with two smooth steel wires and the fence posts were laid 15 meters apart according to the model described by Moura Carvalho et al. (2001).

\subsection{Experimental Animals}

Ten female Murrah buffaloes between four and five years old were used, weighing $479.6 \mathrm{~kg}$ on average, which were chosen for their health status and body condition score to ensure statistical uniformity. Before data collection, the animals remained in the experimental area for 14 days to adapt to the management and feeding conditions. Endo and ectoparasites were controlled prophylactically (Láu, 1999). The buffaloes fed exclusively on pasture with water and mineral salt ad libitum.

\subsection{Data Collection}

Meteorological data were recorded every minute by a portable automated meteorological station (TGD-300, Instrutherm, São Paulo, Brazil) installed in the same microclimate as the pen of the SPS, both in the shaded and non-shaded areas. This device has dry-bulb and wet thermometers to record air temperature, a thermo-hygrometer to measure relative air humidity, and a black-globe thermometer. Thus, data on air temperature and relative humidity, dew point, and black globe temperature were obtained. The environmental variables were recorded in a data logger every minute between 6:00 AM and 5:55 PM during the observations of pasture behavior.

Information was obtained on time spent grazing, ruminating, idling, and in "other activities" for 12 straight hours from 6:00 AM to 6:00 PM, in special file cards of 60 minutes each divided into 12 five-minute periods during the eight data collection campaigns according to methodology adapted from Lourenço Júnior (1998). The females were numbered 1 to 10 with yellow non-toxic paint at the scapular and hindquarter for easier identification. The collection campaigns were always carried out with the animals in the same pen during the two first days of occupation.

For animal behavior assessment, the following activity categories were analyzed: grazing, which considered the time the animal spent grazing; rumination, the sum of the periods the animal ruminated standing or laying; idling, the total time spend standing or lying; and "other activities," which included walking, defecating, drinking water, urinating, and ingesting 


\section{Macrothink

mineral salt. For each activity category, the observers recorded whether the animal performed the activity in a shaded or non-shaded area. The data were collected by observers in cabins 4 $\mathrm{m}$ above the ground installed in the pen occupied by the animals. Data collection was continuous, aiming at a representative observation of animal behavior activity every five minutes. The previously trained observers were replaced every four hours.

\subsection{Statistical Analysis}

The experiment followed a completely randomized design with two treatments: 1 - Female buffaloes in non-shaded area of the silvopastoral system; and 2 - female buffaloes in a shaded area of the silvopastoral system. The data underwent analysis of variance in which the means were computed, as well as graphical analyses of the trends for the variables considered. Three different periods were considered for assessing animal behavior activities: morning period between 6:00 AM and 9:55 AM; intermediary period - between 10:00 AM and 1:55 PM; and afternoon period - between 2:00 PM and 5:55 PM. The software Statistical Analysis System (SAS, 2007) was used for the statistical analyses, with the use of T-test $(\mathrm{P}<0.05)$.

\section{Results}

\subsection{Climate of the Experimental Area}

The air temperature in the shaded area was lower along the day $(\mathrm{P}<0.05)$ when compared to the non-shaded area (Figure 1). Higher values of relative air humidity $(\mathrm{P}<0.05)$ were recorded in the shaded area. The highest values of air temperature were recorded between $11 \mathrm{AM}$ and 2 $\mathrm{PM}$, ranging from 32.57 to $33.80^{\circ} \mathrm{C}$.
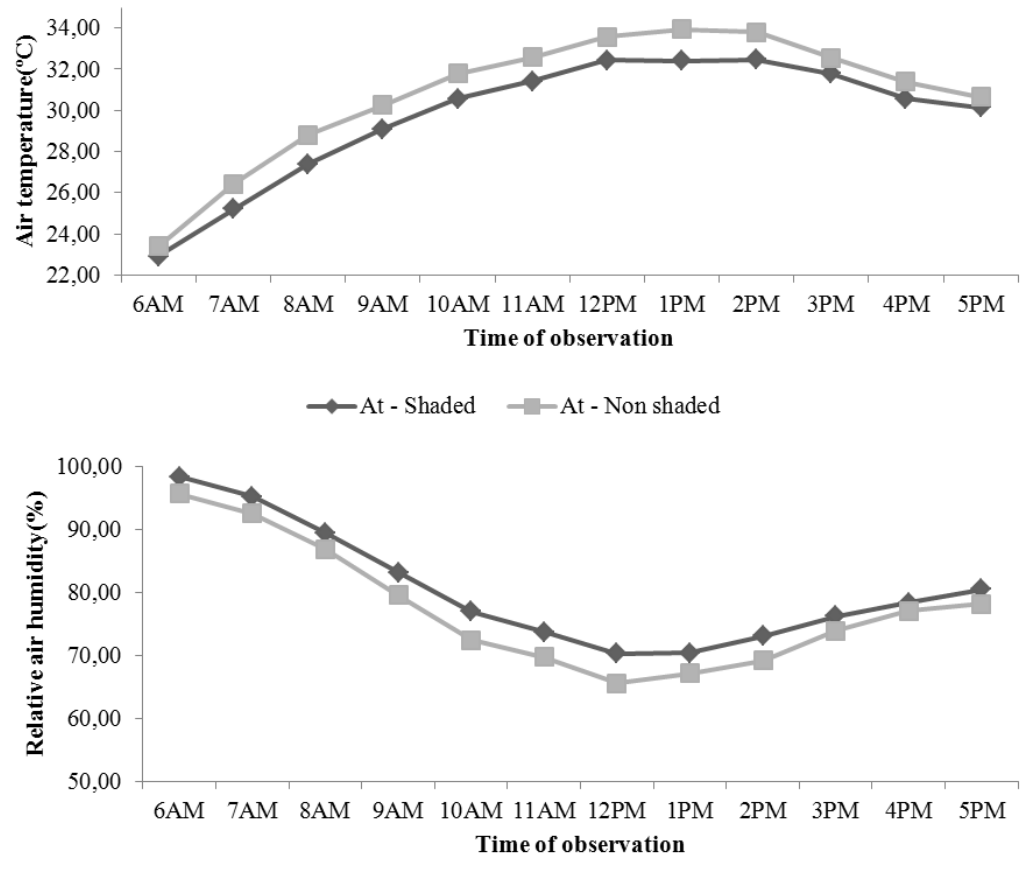

$\leadsto$ RH - Shaded $\quad-$ - RH - Non shaded 


\section{Macrothink}

Figure 1. Average values of the meteorological variables of air temperature $\left(\mathrm{At}\right.$, in $\left.{ }^{\circ} \mathrm{C}\right)$ and relative air humidity (RH, in \%) in the shaded and non-shaded areas of the silvopastoral system under climate conditions of the eastern Amazon

\subsection{Time Spent in Activities}

Figure 2 shows the mean frequency of the time spent in activities of grazing, rumination, idling, and "other activities" over 12 hours of observation. The grazing time was reduced during the hottest hours of the day $(\mathrm{P}<0.05)$, in the intermediary period; however, it was resumed after 4:00 PM, when the environment became milder, with a consequent reduction in rumination and idling. Besides, the other activities such as walking, defecating, drinking water, urinating, and ingesting mineral salt were constant during the whole analyzed period.

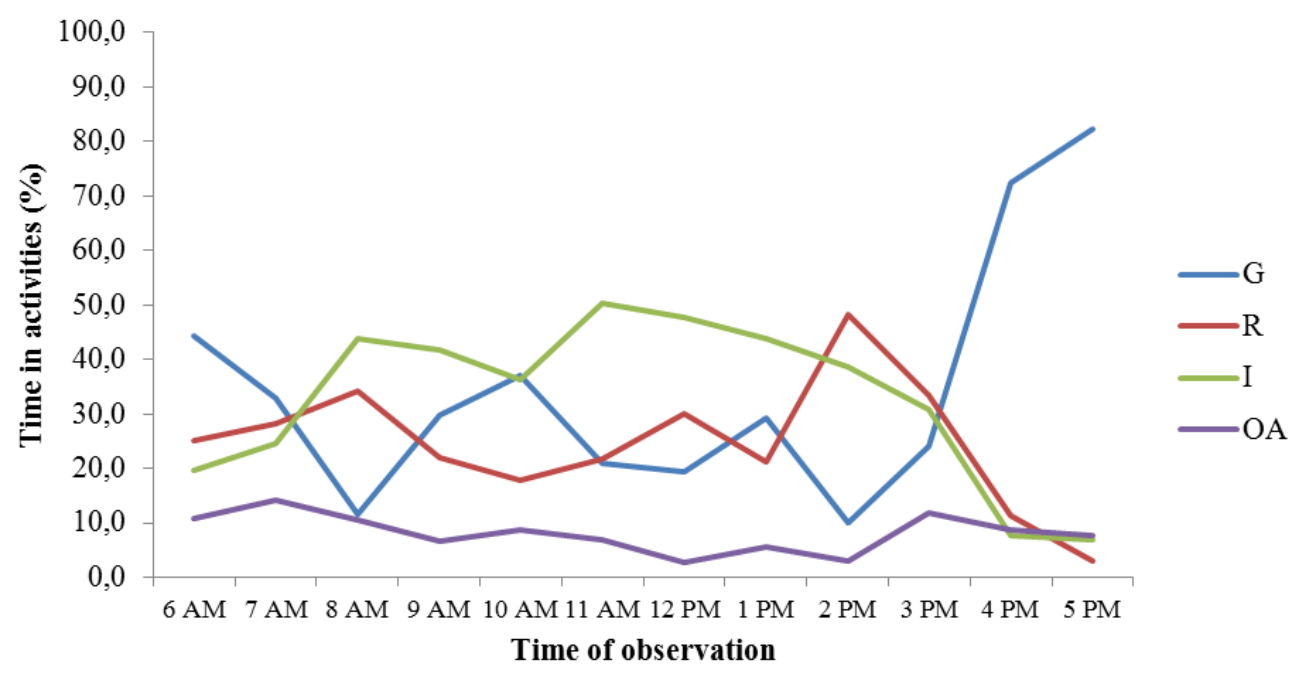

Figure 2. Times of grazing - G, rumination - R, idling - I, and "other activities" - OA (\%) of buffalo females raised in a silvopastoral system (SPS) in climate conditions of the eastern Amazon

The time the female buffaloes stayed in the non-shaded and shaded areas of the SPS over 12 hours of observation is shown in Figure 3. During the hottest hours of the day, in the intermediary period, the buffaloes stayed more time in the shade $(\mathrm{P}<0.05)$. The animals stayed in non-shaded areas in the early morning and after the intermediary period to develop different activities, among which grazing. 


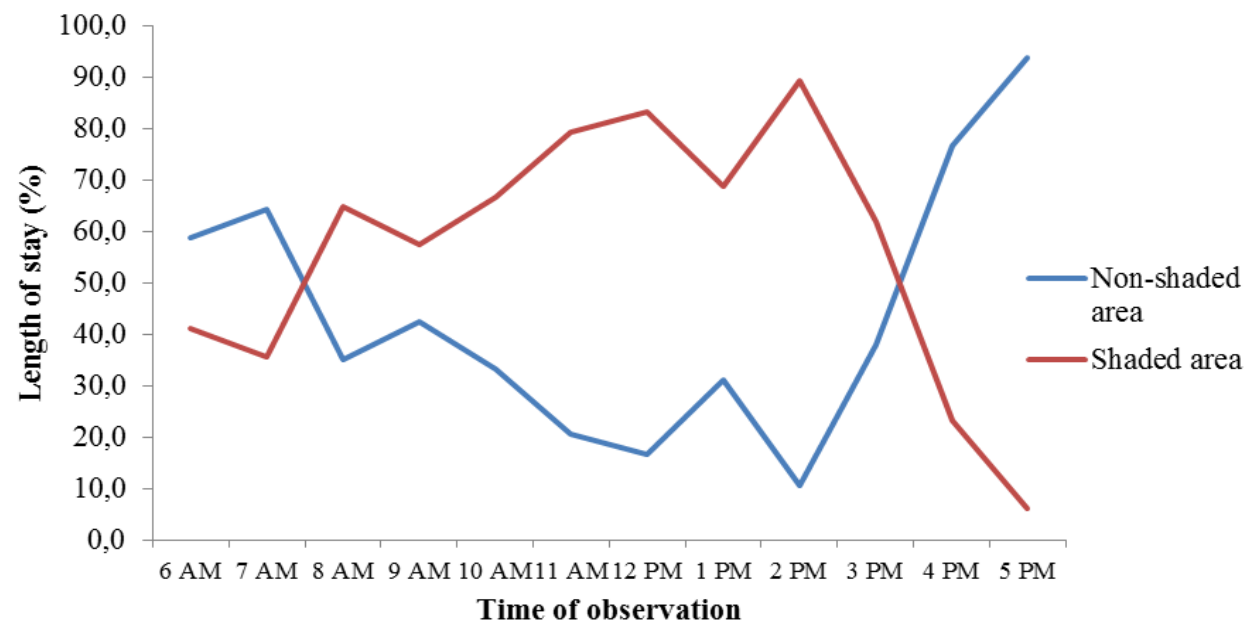

Figure 3. Time female buffaloes stayed (\%) in non-shaded and shaded areas of the silvopastoral system (SPS) over 12 hours of observation in climate conditions of the eastern

Amazon

Table 1 shows the grazing times in the SPS. The grazing times were different in the three periods of the day in the non-shaded area, especially in the afternoon $(\mathrm{P}<0.05)$. The buffaloes grazed in the shaded areas mainly in the hottest hours of the day.

Table 1. Grazing time (\%) of female buffaloes in three periods of the day in the silvopastoral system (SPS) in Belém, Pará, Brazil

\begin{tabular}{lll}
\hline \multirow{2}{*}{ Period } & Grazing $(\%)$ & \\
\cline { 2 - 3 } & Non-shaded & Shaded \\
\hline Morning & $20.26^{\mathrm{bA}}$ & $7.53^{\mathrm{ab}}$ \\
Intermediary & $15.23^{\mathrm{cA}}$ & $8.12^{\mathrm{ab}}$ \\
Afternoon & $55.28^{\mathrm{aA}}$ & $4.44^{\mathrm{bB}}$ \\
\hline
\end{tabular}

Means followed by different small letters in the columns are different $(\mathrm{P}<0.05)$. Means followed by different capital letters in the lines are different $(\mathrm{P}<0.05)$. Periods: Morning $(6$ AM - 9:55 AM), Intermediary (10 AM - 1:55 PM), and Afternoon (2 PM - 5:55 PM).

Table 2 shows the rumination times either lying or standing in the SPS. The rumination times were different $(\mathrm{P}<0.05)$ in the three periods of the day in the shaded area, for lying animals, and it was greater in the intermediary period. This activity stood out in the intermediary period. For standing animals in shaded, the rumination decreased during the day, and it was smallest in the afternoon. Animals that were standing and with no-shaded, ruminated more in the morning. Both lying and standing animals spent more time ruminating in shaded than without shade.

Table 2. Rumination time either lying or standing (\%) of female buffaloes in three periods of the day in the silvopastoral system (SPS) in Belém, Para, Brazil

\begin{tabular}{lcccc}
\hline \multirow{2}{*}{ Period } & \multicolumn{3}{c}{ Lumination (\%) } \\
\cline { 2 - 5 } & Non-shaded & Shaded & Non-shaded & Shaded \\
\cline { 2 - 5 } & $2.84^{\mathrm{ab}}$ & $6.85^{\mathrm{cA}}$ & $7.83^{\mathrm{ab}}$ & $10.86^{\mathrm{aA}}$ \\
Morning & $1.12^{\mathrm{ab}}$ & $14.42^{\mathrm{aA}}$ & $0.81^{\mathrm{bB}}$ & $11.73^{\mathrm{aA}}$ \\
Intermediary & $2.84^{\mathrm{ab}}$ & $9.75^{\mathrm{bA}}$ & $1.52^{\mathrm{bA}}$ & $2.40^{\mathrm{bA}}$ \\
Afternoon & &
\end{tabular}


Means followed by different small letters in the columns are different $(\mathrm{P}<0.05)$. Means followed by different capital letters in the lines are different $(\mathrm{P}<0.05)$. Periods: Morning $(6$ $\mathrm{AM}$ - 9:55 AM), Intermediary (10 AM - 1:55 PM), and Afternoon (2 PM - 5:55 PM).

Table 3 shows the idling time, either lying or standing, in the SPS during the three periods of the day. Similar to rumination, the female buffaloes sought the shaded areas to idle, in either position, mainly in the intermediary period. In the cooler hours of the morning period, the animals spent more time idling in the non-shaded areas unlike in the hotter period, when they sought to perform this activity under the tree canopies so as to cool down.

Table 3. Idling time either lying or standing (\%) of female buffaloes in three periods of the day in the silvopastoral system (SPS) in Belém, Para, Brazil

\begin{tabular}{ccccc}
\hline \multirow{2}{*}{ Period } & \multicolumn{3}{c}{ Lying } & \multicolumn{2}{c}{ Standing } \\
\cline { 2 - 5 } & Non-shaded & Shaded & Non-shaded & Shaded \\
\cline { 2 - 5 } Morning & $4.53 \mathrm{aB}$ & $7.16 \mathrm{bA}$ & $8.88 \mathrm{aB}$ & $13.78 \mathrm{bA}$ \\
Intermediary & $1.60 \mathrm{bB}$ & $22.42 \mathrm{aA}$ & $1.60 \mathrm{bB}$ & $17.81 \mathrm{aA}$ \\
Afternoon & $0.72 \mathrm{bB}$ & $8.64 \mathrm{bA}$ & $2.85 \mathrm{bA}$ & $2.81 \mathrm{cA}$ \\
\hline
\end{tabular}

Means followed by different small letters in the columns are different $(\mathrm{P}<0.05)$. Means followed by different capital letters in the lines are different $(\mathrm{P}<0.05)$. Periods: Morning $(6$ $\mathrm{AM}$ - 9:55 AM), Intermediary (10 AM - 1:55 PM), and Afternoon (2 PM - 5:55 PM).

Table 4 shows the time spent in "other activities" in the SPS during the three periods of the day, which were carried out by the female buffaloes in the early morning and late afternoon in the non-shaded areas. In the SPS, in the three periods of the day, the "other activities" were performed by the female buffaloes basically in the early morning and late afternoon in the non-shaded areas.

Table 4. Time of other activities (\%) of female buffaloes in three periods of the day in the silvopastoral system (SPS) in Belém, Para, Brazil

Period

Other activities $(\%)$

\begin{tabular}{lcc}
\cline { 2 - 3 } & Non-shaded & Shaded \\
\hline Morning & $6.28^{\mathrm{aA}}$ & $2.55^{\mathrm{aB}}$ \\
Intermediary & $2.59^{\mathrm{bA}}$ & $1.35^{\mathrm{bB}}$ \\
Afternoon & $5.97^{\mathrm{aA}}$ & $0.97^{\mathrm{bB}}$ \\
\hline
\end{tabular}

Means followed by different small letters in the columns are different $(\mathrm{P}<0.05)$. Means followed by different capital letters in the lines are different $(\mathrm{P}<0.05)$. Periods: Morning $(6$ AM - 9:55 AM), Intermediary (10 AM - 1:55 PM), and Afternoon (2 PM - 5:55 PM).

\section{Discussion}

\subsection{Climate of the Experimental Area}

The lower air temperature in the shaded area, when compared to the non-shaded area, can be explained by the presence of trees, which blocked the direct solar radiation and provided a 
milder microclimate to the animals. One of the main stress agents in field cattle farming systems is the physical environment variables, especially solar radiation and air temperature (Romanello et al., 2018). In conditions with high temperature and relative air humidity, the animals dissipate heat by changing fixed behavior patterns and times standing and lying in search of milder environments (Schütz et al., 2008; Schütz et al., 2009).

\subsection{Time Spent in Activities}

Regarding the times of grazing, rumination, idling, and "other activities," the reduced grazing during the hottest hours of the day, in the intermediary period, was likely due to the higher incidence of solar radiation and high air temperatures. This way, the buffaloes sought shaded areas for thermal comfort. This activity was resumed after 4:00 PM, when the environment became milder, with a consequent reduction in rumination and idling. During the hottest hours of the day, the animals reduce their activities related to feeding (intake and rumination) and increase idling in an attempt to reduce heat production. These results are in accordance with those by Lourenço Júnior (1998), who reported a greater peak in grazing in the morning and after 3:00 PM. A similar behavior took place with other activities, considered complementary, which involve drinking water, defecating, urinating, eating salt, and walking.

In the hottest hours of the day, in the intermediary period, the buffaloes spent more time in the shaded areas, where the microclimate is less stressful and, consequently, provides animal welfare (Silva et al., 2011). These animals stayed in non-shaded areas in the early morning and after the intermediary period to perform different activities, among which grazing, due to the better climate conditions at these times. Similar results were found by Titto et al. (2011) and Schütz et al. (2009). The change in behavior is the first biological response to the stress agent since, when the animals have a threat to their homeostasis, the central nervous system is stimulated and the organism reacts, with biological responses, in an attempt to protect itself and cope with the potential harmful effects (Peters et al., 2007).

The grazing times were different in the three periods of the day in the non-shaded area, especially in the afternoon. The buffaloes grazed in the shaded areas mainly in the hottest hours of the day. It must be pointed out that grazing time is greater in non-shaded areas since they represented the highest percentage in the SPS at around $90 \%$.

Considering that the system did not have bathing water in lakes or reservoirs, which are common forms of thermoregulation through the thermal exchange for these animals (Marai and Haeeb, 2010), a greater search for the shaded areas was seen in the hottest hours so they could cool down. Likewise, mainly during the rainy season, the animals used the rain and water in puddles to cool down. This fact matches the results of Ablas et al. (2007), who concluded that, when there is water and shade available, buffaloes prefer water.

The rumination times were different $(\mathrm{P}<0.05)$ in the three periods of the day in the shaded area. This activity stood out in the intermediary period. In the early morning and late afternoon, intense rumination activity was seen standing, at hours that coincided with lower solar radiation and lower air temperature, thus of greater comfort to the animals. The animals prefer to perform this activity in the cooler periods of the day to make up for the greater 
production of internal heat, results that match those of Garcia et al. (2011).

Similar to rumination, the female buffaloes sought the shaded areas to idle, in either position, mainly in the intermediary period so as to perform this activity with greater thermal comfort. Chiquitelli Neto (2005) recorded a longer idling time of the animals in the shaded area when compared to the direct exposition to sunlight. In the cooler hours of the morning period, the animals spent more time idling in the non-shaded areas unlike in the hotter period, when they sought to perform this activity under the tree canopies so as to cool down. In the SPS, in the three periods of the day, the "other activities" were performed by the female buffaloes basically in the early morning and late afternoon in the non-shaded areas. The similarity of the time spent for "other activities" along the day, including drinking water, maybe due to the presence of trees, which, according to Castro et al. (2008) and Moraes Júnior et al. (2010), provide a comfortable environment for the animals to perform their different activities without thermal discomfort.

\section{Conclusion}

The female bulls spend more time grazing in the milder hours of the day so as to avoid the harmful effects of the high incidence of solar radiation and high air temperatures of the humid Amazonian tropical climate. These adverse conditions, mainly in the dry season of the year, require environment management practices that enable better thermal comfort to the animals in a field cattle farming system through the control of the climate effects. Thus, silvopastoral systems may contribute to water buffalo welfare, which maintains their fixed behavior pattern and increases production performance.

\section{Acknowledgments}

To the Amazon Development Authority - SUDAM, to the Brazilian Agricultural Research Corporation - Embrapa, to the Federal Rural University of the Amazon - UFRA, and to the Coordination for the Improvement of Higher Education Personnel - CAPES for the availability of resources needed for the experiment. ARG is CNPq - National Council for Scientific and Technological Development fellow.

\section{References}

Ablas, D. S., Titto, E. A. L., Pereira, A. M. F., Titto, C. G., \& Leme, T. M. C. (2007). Behaviour of grazing water buffaloes depending on the availability of shade and water for immersion. Ciência Animal Brasileira, 8(2), 167-175.

Castro, A. C., Lourenço Júnior, J. B., Santos, N. F. A., Monteiro, E. M. M., Aviz, M. A. B., \& Garcia, A. R. (2008). Silvopastoral system in the Amazon region: tool to increase the productive performance of buffaloes. Ciência Rural, 38(8), 2395-2402. https://doi.org/10.1590/S0103-84782008000800050

Chiquitelli Neto, M. (2005). Artificial shading how technology to elevate the economic efficiency and welfare of bovine meat production. 2005. Tese - Universidade Estadual Paulista Júlio de Mesquita Filho/Faculdade de Ciências Agrárias e Veterinárias, Jaboticabal, São Paulo, 77p. 
Falesi, I. C., \& Baena, A. R. C. (1999). African mahogany (Khaya ivorensis A. Chev.) in a silvopastoral system with legume and coat natural soil (52 p.). Belém, PA: Embrapa Amazônia Oriental.

Garcia, A.R., Matos, L. B., Lourenço Júnior, J. B., Nahúm, B. S., Araújo, C. V., \& Santos, A. X. (2011). Variáveis fisiológicas de búfalas leiteiras criadas sob sombreamento em sistemas silvipastoris. Pesquisa Agropecuária Brasileira, 46(10), 1409-1414. https://doi.org/10.1590/S0100-204X2011001000039

Giro, A., Pezzopane, J. R. M., Barioni Junior, W., Pedroso, A. F., Lemes, A .P., Botta, D., Romanello, N., Barreto, A. D. N., \& Garcia, A. R. (2019). Behavior and body surface temperature of beef cattle in integrated crop-livestock systems with or without tree shading. Science of Total Environment, 20(684), 587-596. doi:10.1016/j.scitotenv.2019.05.377.

Láu, H. D. (1999). Desease in buffalos on Brazil: diagnosis, epidemiology and control. (202 p.) 1ed. Brasília: Embrapa.

Lourenço Júnior, J. B., Variáveis produtivas, fisiológicas e de comportamento de zebuínos e bubalinos e fatores do ambiente físico em pastagem cultivada da ilha de Marajó. 1998. Tese (Doutorado em Ciências Biológicas) - Universidade Federal do Pará, Belém, PA. https://www.bdpa.cnptia.embrapa.br/consulta/busca

Marai, I. F. M., \& Haeeb, A. A. M. (2010). Buffalo's biological functions as affected by heat stress -a review. Livestock Science, 127, 89-109. https://doi.org/10.1016/j.livsci.2009.08.001

Moraes Júnior, R. J., Garcia, A.R., Santos, N. F. A., Lourenço Júnior, J. B., \& Nahum, B. S. (2010). Effects of the Silvopastoral Systems in the Environmental Comfort of Buffalo Calves (Bubalus bubalis) in the Eastern Amazon. Revista Veterinária, 21, 788-791.

Moura Carvalho, L. O. D., Costa, N. A., Lourenço Júnior, J. B., \& Baena, A. R. C. (2001). Electric fence to contain animals. (22 p.) Belém: Emater.

Pachêco, N. A., Santiago, A. V., Bastos, T. X., \& Cordeiro, A. H. F. (2009). Boletim Agrometerorológico de 2009 para Belém, PA. (38p.). Belém:Documentos/Embrapa Amazônia Oriental.

Parola, F., Hillmann, E., Schütz, K. E., \& Tucker, C. B. (2012). Preferences for overhead sprinklers by naïve beef steers: Test of two nozzle types. Applied Animal Behaviour Science. 137(1-2), 13-22. https://doi.org/10.1016/j.applanim.2011.12.010

Peters, M. D. P., Silveira, I. D. B., \& Rodrigues, C. M. (2007). Interaction human and bovine milk. Archivos de Zootecnia, 55, 9-23.

Pezzopane, J. R. M., Nicodemo, M. L. F., Bosi, C., Lulu, J., \& Garcia, A. R. (2019). Animal thermal comfort indexes in silvopastoral systems with different tree arrangements. Journal of Thermal Biology, 79, 103-111. doi:10.1016/J.JTHERBIO.2018.12.015

Rhoads, M. L., Rhoads, R. P., VanBaale, J. J., Collier, R. J., Sanders, S. R., Weber, W. J., Crooker, B. A., \& Baumgard, L. H. (2009). Effects of heat stress and plane of nutrition on 


\section{Macrothink

lactating Holstein cows: I. Production, metabolism, and aspects of circulating somatropin. Journal of Dairy Science, 92, 1986-1997. https://doi.org/10.3168/jds.2008-1641

Romanello, N., Lourenço Junior, J. B., Barioni Junior, W., Brandão, F. Z., Marcondes, C. R., Pezzopane, J. R. M., Pantoja, M. H. A., Botta, D., Giro, A., Moura, A. B. B., Barreto, A. N., \& Garcia, A. R. (2018). Thermoregulatory responses and reproductive traits in composite beef bulls raised in a tropical climate. International Journal of Biometeorology, 62(9):1575-1586. doi:10.1007/s00484-018-1557-8.

SAS. (2007). Statistical Analysis System - SAS. (1028p.) Institute Inc. SAS/STAT User's Guide. Cary, NC: SAS Institute Inc.

Schütz, K. E., Cox, N. R., \& Matthews, L. R. (2008). How important is shade to dairy cattle? Choice between shade or lying following different levels of lying deprivation. Applied Animal Behaviour Science, 114, 307-318. https://doi.org/10.1016/j.applanim.2008.04.001

Schütz, K. E., Rogers, A. R., Neil, R. C., \& Tucker, C. B. (2009). Dairy cows prefer shade that offers greater protection against solar radiation in summer: Shade use, behavior, and body temperature. Applied Animal Behaviour Science, 116, 28-34. https://doi.org/10.1016/j.applanim.2008.07.005

Silva, J. A. R., Araújo, A. A., Lourenço Junior, J. B., Santos, N. F. A., Garcia, A. R., \& Nahúm, B. S. (2011). Conforto térmico de búfalas em sistema silvipastoril na Amazônia Oriental. Pesquisa Agropecuária Brasileira, 46, 1364-1371. https://doi.org/10.1590/S0100-204X2011001000033

Titto, C. G., Titto, E. A. L., Titto, R. M., \& Mourão, G. B. (2011). Heat tolerance and the effects of shade on the behavior of Simmental bulls on pasture. Animal Science Journal, 82, 591-600. https://doi.org/10.1111/j.1740-0929.2011.00872.x

\section{Copyright Disclaimer}

Copyright for this article is retained by the author(s), with first publication rights granted to the journal.

This is an open-access article distributed under the terms and conditions of the Creative Commons Attribution license (http://creativecommons.org/licenses/by/4.0/). 